\title{
Anti-CD3 Monoclonal Antibody
}

National Cancer Institute

\section{Source}

National Cancer Institute. Anti-CD3 Monoclonal Antibody. NCI Thesaurus. Code C112883.

Any monoclonal antibody directed ag ainst the cell surface glycoprotein CD3, regardless

of the antibody type. 